\title{
Vitamin D Status and Spontaneous Intra Cerebral Hemorrhage: Would it be Able to Help?
}

\author{
ABEER A. TONY, M.D.*; EFFAT A. TONY, M.D.**; EMAD F. KHOLEF, M.D.*** and \\ WAFAA S. MOHAMMED, M.D.*** \\ The Departments of Neurology*, Internal Medicine ** and Clinical Pathology***, Faculty of Medicine, \\ Aswan*,*** and Assiut** Universities, Egypt
}

\begin{abstract}
Background: Vitamin D deficiency has in like manner rose as a hazard factor for cerebrovascular stroke. It is questionable if vitamin D status impacts the anticipation of patients who have created intracerebral hemorrhage. In Aswan governate, most of people had low vitamin D levels in spite of its sunny weather, as well as increased number of hemorrhagic stroke.

Aim of Study: Consequently, our study planned to look at the connection between serum $25(\mathrm{OH}) \mathrm{D}$ status and hemorrhagic stroke, to clear up their relationship with stroke seriousness, and to evaluate its connection with functional outcome and mortality in our considered patients.

Patients and Methods: This prospective cross sectional study directed on 125 patients with first time acute stroke with spontaneous intracerebral hemorrhage. All members exposed to full history taking, detailed clinical examination and neurological checking. Brain imaging was performed after hospital admission. Blood tests were drawn for appraisal of serum 25-hydroxyl vitamin D and parathyroid hormone on the first day of admission.
\end{abstract}

Results: $44 \%$ and $40 \%$ of examined patients with intracerebral hemorrhage had lacking and inadequate vitamin D levels respectively. There was a relationship between intracerebral hemorrhage with vitamin D levels, and the severity of the stroke and functional outcome. In dead patients with intracerebral hemorrhage, a low vitamin D level was detectable.

Conclusion: Vitamin D deficiency may have a relationship with acute intracerebral hemorrhage and its pervasive hazard factors among individuals in Upper Egypt (Aswan). Low levels of vitamin D are freely prescient for deadly strokes with more confirmation of negative result in acute intracerebral hemorrhage. Consequently, It may be a marker of more noteworthy comorbidity and a being causally identified with stroke proposing that vitamin D supplementation is a promising approach in the preventive action of strokes. Further studies are needed to investigate this relationship among different territories of Egypt and for stroke subtypes.

Correspondence to: Dr. Abeer A. Tony, The Department of Neurology, Faculty of Medicine, Aswan University, Egypt
Key Words: Acute stroke - Scandinavian Stroke Scale (SSS) - Modified Rankin Scale (mRS) - Serum 25hydroxyvitamin D - Parathyroid hormone (PTH).

\section{Introduction}

STROKE stays a standout amongst the most uncontrollable neurological disorders causing death, or physical incapacitating [1]. Intracerebral hemorrhage ( $\mathrm{ICH})$ has the most prominent mortality rate of stroke subtypes. ICH represents just $15 \%$ of all strokes however it is a standout amongst the most types of stroke [2]. In up to $85 \%$ of patients, ICH is the aftereffect of small vessel malfunction, which has traditionally been credited to hypertensive vasculopathy though in elderly patients is ascribed to a gathering of amyloid- $(3$ in leptomeningeal and cortical blood vessels [3].

Since stroke exhibits a high morbidity and death rate, investigating its systems can be compelling in its counteractive action [4]. Vitamin D insufficiency is related to the expanded danger of stroke. The connection between vitamin $\mathrm{D}$ and the hazard and anticipation of stroke is as yet indistinct. A few examinations demonstrated that durable low $25(\mathrm{OH}) \mathrm{D}$ levels may show a high danger of stroke [5]. Huge opposite relationship between $25(\mathrm{OH})$ $D$ levels and stroke hazard are documented $[6,7]$. Causal mechanisms have been connected to the relationship of vitamin D lack with the existence of hypertension, diabetes mellitus, atherosclerosis, thrombosis, and inflammation.

Nonetheless, the proof is conflicting [8,9]. Moreover, Vitamin D may assume a part in neuroprotection, may be through detoxification pathways, hindrance of inducible nitric oxide synthase, antioxidation/anti-inflammatory mechanisms, neuronal 
calcium direction or upgraded nerve conduction [10]. Low serum $25(\mathrm{OH}) \mathrm{D}$ level is an indicator of seriousness at admission, poor early functional outcome and is likewise an indicator of here and now mortality in stroke patients [11,12]. In Aswan governate, we observed that most of people had low vitamin D levels in spite of its sunny weather, as well as increased number of hemorrhagic stroke. Therefore, In the present work, we tried the connection between serum $25(\mathrm{OH}) \mathrm{D}$ levels and hemorrhagic stroke, to anticipate their connection with stroke severity, stroke risk factors and to evaluate its connection with functional outcome in our contemplated patients.

\section{Subjects and Methods}

This prospective cross sectional investigation was led on 125 patients with first-ever acute onset intracerebral hemorrhage that were enlisted from the stroke unit of Neuropsychiatric Department, Aswan University Hospital in the period from September 2016 to April 2017.

Patients were incorporated on if they had an acute stroke with manifestation beginning within 24-48 hours which was affirmed by brain imaging. Their ages between 25-87 years of age (mean age was $62.32 \pm 11.38$ years). The mean length from stroke beginning to the consideration in this examination was $9.5 \pm 8.5$ hours. Patients with ischemic stroke, history of past stroke, cerebral amyloid angiopathy, vascular malformations and aneurysms, patients with cerebral hemorrhage with either intraventricular extension or hydrocephalic changes on brain imaging, brain neoplasm, endocrinal disorders, hepatic and renal disability, past fractures, bone diseases, vitamin D or Ca supplementation, steroid treatment were excluded. All patients are classified according to the vitamin D level into three groups; first group has sufficient $(>50 \mathrm{nmol} / \mathrm{L})$, second group has insufficient $(25-50 \mathrm{nmol} / \mathrm{L})$ and third group has deficient $(<25 \mathrm{nmol} / \mathrm{L})$ vitamin $\mathrm{D}$ levels. The examination has been affirmed by the ethical and moral council of Faculty of Medicine, Aswan University and a written informed consent will be getting from every member.

\section{Methods:}

All members were subjected to complete history and full clinical examination with the total neurological examination. The severity of the stroke was assessed by Scandinavian Stroke Scale (SSS) and functional outcome was determined by Modified Rankin Scale (mRS) that were estimated early during of hospitalization. A mRS $\leq 2$ was defined as favorable outcome, and a mRS $>2$ was defined as unfavorable outcome including death. Brain CT was performed at admission. $10 \mathrm{ml}$ of venous blood were gathered from the included patient: $2 \mathrm{ml}$ in EDTA tube for complete blood count (has been done on Sysmex XP-300 cell counter) and 8ml isolated on two plan tubes (for serum collection) for standard and unique parameter estimation; samples had been left to clot. Centrifugation for all samples at 3000rpm for 20min subsequent to coagulating. Serum was isolated and separated into 3 parts: One for routine parameter estimation (random blood glucose, renal and liver function tests, thyroid hormone level, lipid profile, calcium and phosphorus levels); all parameters were done on completely computerized chemistry analyzer BT-3500 (Italy). The other 2 parts were stored at $-20^{\circ} \mathrm{C}$ for later use for estimation of 1,25-dihydroxy Vitamin D and Parathyroid hormone (PTH) utilizing a Sandwich ELISA system (Calbiotech Inc. 10461 Austin Dr, Spring Valley, CA). All blood samples were collected on the first day of admission and hemolyzed samples were excluded.

\section{Statistical analysis:}

Data was analyzed using the (SPSS 20.0 software, Chicago, IL, USA) computer program. The normality of the data was determined by Kolmogorov-Smirnov test. Data were figured as mean $\pm \mathrm{SD}$, median (range) or numbers and percentages when appropriate. Chi-square test and Fisher exact test was used to compare between categorical variables. Continuous variables were compared by $t$-test (normally distributed data) and Mann-Whitney (not normal distributed data). Comparison between the groups was carried out using one way analysis of variance for quantitative variables (ANOVA). A two-tailed $p<0.05$ was considered statistically significant.

\section{Results}

The initial demographic and clinical characteristics of studied patients with acute intracerebral hemorrhage are shown in Table (1). The mean age of tested patients was $62.32 \pm 11.38$ years. Male sex was $60 \%$ of patients. All patients had an unfavorable functional outcome of a high percent $(100 \%)$ with high MRS score $(5 \pm 0.7)$. Scandinavian stroke scale was $19.8 \pm 10.7$. Most of them $(80 \%)$ were hypertensive with mean systolic and diastolic blood pressure was $159.8 \pm 13.2$ and $95.4 \pm 10.2 \mathrm{mmHg}$ respectively. $68 \%$ and $60 \%$ of the patients had dyslipidemia and DM, respectively. Smoking was distinguished in one third of patients (40\%). Death was about one-third of patients (28\%). 
The patients had normal mean levels of serum $\mathrm{Ca}(9.17 \pm 1.63 \mathrm{mg} / \mathrm{dl})$ with high mean levels of serum phosphorus $(4.70 \pm 0.85 \mathrm{mg} / \mathrm{dl})$. The majority of our studied patients had low mean levels of vitamin $\mathrm{D}$; deficient and insufficient levels of vitamin $\mathrm{D}(<25 \mathrm{nmol} / \mathrm{L}$ in $44 \%$ and $>25-<50 \mathrm{nmol} / \mathrm{L}$ in $40 \%$ patients) respectively. Notably, our patients had high mean levels of parathyroid hormone level (72.02 \pm 59.06$)$ as shown in Table (2).

It was noticed that patients group had significantly lower vitamin $\mathrm{D}$ in comparison to the control group (35.48 \pm 14.28 vs. $60.31 \pm 21.22 ; p<0.001)$. Patients with Sufficient level of vitamin D had insignificantly lower vitamin D in comparison to the control group but control group had significantly higher vitamin $\mathrm{D}$ in comparison to those patients with insufficient or deficient vitamin $\mathrm{D}$ as shown in Table (3) and Fig. (1a,b).

There were statistically significant higher frequencies of risk factors; Diabetes Mellitus, Hypertension and Dyslipidemia in the studied patients in presence of more decline of mean levels of vitamin D (Deficient $<25 \mathrm{nmol} / \mathrm{L}$ ) when compared to those patients with sufficient $(>50 \mathrm{nmol} / \mathrm{L})$ or insufficient $(25-50 \mathrm{nmol} / \mathrm{L})$ vitamin D levels with $p>0.01, p>0.04$ and $p>0.04$ respectively as shown in Table (4).

Patients with ICH and low vitamin D level had significantly more severe stroke presentation (lower SSS score $16.74 \pm 8.08$ ) in comparison to those with ICH and normal vitamin D level (29.50 \pm 12.41 ; $p=0.002$ ). Also, patients with ICH and low vitamin $\mathrm{D}$ level had significantly more bad functional outcome (higher mRS 4.89 \pm 0.31 ) in comparison to those with $\mathrm{ICH}$ and normal vitamin D level $(4.33 \pm 0.47 ; p=0.03)$ as shown in Table (5).

It was noticed that mean serum phosphorus level was significantly higher among dead patients than survivors $(5.16 \pm 0.41$ versus $4.53 \pm 0.83 \mathrm{mg} / \mathrm{dl}$ respectively; $p=0.00$ ) while survivors had significantly higher mean vitamin D level (38.93 \pm 8.93 versus $22.56 \pm 5.4 \mathrm{mg} / \mathrm{dl}$ respectively; $p=0.00$ ). Notably, there were lower serum levels of iPTH in survivors when compared to that levels in deaths without a statistically significant difference as shown in Table (6).

By using Multivariate regression analysis for predictors of death in patients with intracerebral hemorrhage, it was noticed that deficiency of vitamin $\mathrm{D}(<50 \mathrm{nmol} / \mathrm{L})(\mathrm{OR}=2.33,95 \% \mathrm{CI}=3.44$ $-5.89, p=0.03)$, diabetes mellitus $(\mathrm{OR}=3.18,95 \%$ $\mathrm{CI}=2.56-5.67, p=0.02)$ and hypertension $(\mathrm{OR}=1.45$,
$95 \% \mathrm{CI}=1.904 .65, p=0.01)$ were predictors of death in patients with cerebrovascular stroke as shown in Table (7).

In Figs. (2-5) vitamin D in subjected patients had a statistically significant positive correlation with stroke severity, assessed by SSS ( $r=0.43$ and $p=0.00$ ), while it had a statistically significant negative correlation with the functional outcome measured by $\mathrm{mRS}(r=-0.39$ and $p=0.00)$. Intact Parathyroid hormone (iPTH) had a statistically insignificant correlation with functional outcome (mRS) and stroke severity (SSS) while it had a negative significant weak correlation with vitamin $\mathrm{D}(r=-0.2 ; p=0.04)$.

Table (1): Basic characteristics of the studied patients.

\begin{tabular}{|c|c|}
\hline Parameters & $\begin{array}{l}\text { Patients with intracerebral } \\
\text { hemorrhage }(\mathrm{No}=125)\end{array}$ \\
\hline Age, years (Mean \pm SD) & $62.32 \pm 11.38$ \\
\hline Sex (male/female) $(\%)$ & $75 / 50(60 \% / 40 \%)$ \\
\hline $\begin{array}{l}\text { Duration of stroke (hours) } \\
(\text { Mean } \pm \text { SD) }\end{array}$ & $9.5 \pm 8.5$ \\
\hline $\begin{array}{l}\text { Modified Rankin scale (mRS) } \\
(\text { Mean } \pm \text { SD })\end{array}$ & $5 \pm 0.7$ \\
\hline $\begin{array}{l}\text { Scandinavian stroke scale (SSS) } \\
(\text { Mean } \pm \text { SD) }\end{array}$ & $19.8 \pm 10.7$ \\
\hline Unfavorable outcome (\%) & $125(100 \%)$ \\
\hline Number of deaths (\%) & $35(28 \%)$ \\
\hline $\begin{array}{l}\text { Blood pressure (mean } \pm S D) \text { : } \\
\text { SBP }(\mathrm{mm} \mathrm{Hg}) \\
\text { DBP }(\mathrm{mm} \mathrm{Hg})\end{array}$ & $\begin{array}{l}159.8 \pm 13.2 \\
95.4 \pm 10.2\end{array}$ \\
\hline $\begin{array}{l}\text { Risk factors: }(\%) \\
\text { Hypertension } \\
\text { Diabetes Mellitus } \\
\text { Dyslipidemia } \\
\text { Smoking }\end{array}$ & $\begin{array}{l}100(80 \%) \\
90(75 \%) \\
85(68 \%) \\
50(40 \%)\end{array}$ \\
\hline Creatinine (mg/dl) & $1.1 \pm 0.33$ \\
\hline Total cholesterol (TC) (mmol/L) & $194.54 \pm 35.17$ \\
\hline LDL-C (mmol/L) & $127.97 \pm 19.95$ \\
\hline HDL-C (mmol/L) & $48.84 \pm 4.67$ \\
\hline Triglycerides (TG) (mmol/L) & $126.12 \pm 40.1$ \\
\hline $\begin{array}{l}\text { Random blood glucose (RBG) } \\
(\mathrm{mg} / \mathrm{dl})\end{array}$ & $192.69 \pm 86.88$ \\
\hline Free T 3 & $3.15 \pm 0.77$ \\
\hline Free T4 & $17.10 \pm 3.56$ \\
\hline $\mathrm{TSH}$ & $0.81 \pm 0.58$ \\
\hline $\begin{array}{l}\text { Erythrocyte sedimentation rate } \\
\text { (ESR) }\end{array}$ & $70.12 \pm 16.74$ \\
\hline
\end{tabular}


Table (2): Laboratory characteristics of studied patients.

\begin{tabular}{|c|c|}
\hline Parameters & $\begin{array}{l}\text { ts with intracerebral } \\
\text { lorrhage }(\mathrm{No}=125)\end{array}$ \\
\hline $\begin{array}{l}\text { Serum total Calcium level (mg/dl) } \\
(\text { Mean } \pm \text { SD) }\end{array}$ & $9.17 \pm 1.6$ \\
\hline $\begin{array}{l}\text { Serum phosphorus level (mg/dl) } \\
(\text { Mean } \pm \text { SD) }\end{array}$ & $4.70 \pm 0.8$ \\
\hline $\begin{array}{l}\text { Parathormone hormone (i PTH) (ng/l) } \\
(\text { Mean } \pm \text { SD) }\end{array}$ & $72.02 \pm 59.06$ \\
\hline $\begin{array}{l}\text { Vitamin D level }(\mathrm{nmol}) \\
(\text { Mean } \pm \text { SD })\end{array}$ & $34.48 \pm 21.27$ \\
\hline \multicolumn{2}{|l|}{ Vitamin D status (\%): } \\
\hline Sufficient $(>50 \mathrm{nmol} / \mathrm{L}) \%$ & $20(16 \%)$ \\
\hline Insufficient $(>25-50 \mathrm{nmol} / \mathrm{L}) \%$ & $50(40 \%)$ \\
\hline Deficient $(<25 \mathrm{nmol} / \mathrm{L}) \%$ & $55(44 \%)$ \\
\hline
\end{tabular}

Data was expressed in form of mean \pm SD.

$p$-value was significant if $<0.05$.

*: Student $t$-test was used. n: Number.

Table (3): Vitamin D status and Risk factors in the studied patients.

\begin{tabular}{lcccc}
\hline Variables & $\begin{array}{c}\text { Sufficient } \\
(>50 \\
\mathrm{nmol} / \mathrm{L})\end{array}$ & $\begin{array}{c}\text { Insufficient } \\
(25-50 \\
\mathrm{nmol} / \mathrm{L})\end{array}$ & $\begin{array}{c}\text { Deficient } \\
(>25 \\
\mathrm{nmol} / \mathrm{L})\end{array}$ & $\begin{array}{c}p- \\
\text { value }\end{array}$ \\
\hline $\begin{array}{c}\text { Diabetes mellitus } \\
(\mathrm{n}=90)\end{array}$ & $12(13.6 \%)$ & $16(18.1 \%)$ & $62(68.3 \%)$ & 0.01 \\
$\begin{array}{c}\text { Hypertension } \\
(\mathrm{n}=100)\end{array}$ & $10(10 \%)$ & $30(30 \%)$ & $60(60 \%)$ & 0.04 \\
$\begin{array}{c}\text { Smoking }(\mathrm{n}=50) \\
\begin{array}{c}\text { Dyslipidemia } \\
(\mathrm{n}=85)\end{array}\end{array}$ & $15(30 \%)$ & $17(34 \%)$ & $18(36 \%)$ & 0.88 \\
\end{tabular}

- Data was expressed in form of frequency (percentage) and one way ANOVA.

$p$-value was significant if $<0.05$.

Table (4): Vitamin D status and Risk factors in the studied patients.

\begin{tabular}{lcccc}
\hline & \multicolumn{3}{c}{ State of vitamin D } & \\
\cline { 2 - 4 } Variables & $\begin{array}{c}\text { Sufficient } \\
(>50 \\
\mathrm{nmol} / \mathrm{L})\end{array}$ & $\begin{array}{c}\text { Insufficient } \\
(25-50 \\
\mathrm{nmol} / \mathrm{L})\end{array}$ & $\begin{array}{c}\text { Deficient } \\
(<25 \\
\mathrm{nmol} / \mathrm{L})\end{array}$ & $\begin{array}{c}p^{-} \\
\text {value }\end{array}$ \\
\hline $\begin{array}{c}\text { Diabetes } \\
\text { mellitus } \\
(\mathrm{n}=110)\end{array}$ & $15(13.6 \%)$ & $20(18.1 \%)$ & $75(68.3 \%)$ & 0.01 \\
$\begin{array}{c}\text { Hypertension } \\
(\mathrm{n}=100)\end{array}$ & $10(10 \%)$ & $30(30 \%)$ & $60(60 \%)$ & 0.04 \\
$\begin{array}{c}\text { Smoking } \\
(\mathrm{n}=90)\end{array}$ & $30(33.3 \%)$ & $30(33.3 \%)$ & $30(33.3 \%)$ & 0.88 \\
$\begin{array}{c}\text { Dyslipidemia } \\
(\mathrm{n}=100)\end{array}$ & $20(20 \%)$ & $30(30 \%)$ & $50(50 \%)$ & 0.04 \\
\hline $\begin{array}{c}\text { Data was expressed in form of frequency (percentage) and one way } \\
\text { ANOVA. } p \text {-value was significant if }<0.05 .\end{array}$ &
\end{tabular}

Table (5): Effect of vitamin D status on the severity and functional outcome in our studied patients.

\begin{tabular}{lccc}
\hline & \multicolumn{2}{c}{$\begin{array}{c}\text { Patients with intracranial } \\
\text { hemorrhage }\end{array}$} & $\begin{array}{c}p \text { - } \\
\text { varameters }\end{array}$ \\
\cline { 2 - 3 } & \multicolumn{2}{c}{$\begin{array}{c}\text { With low } \\
\text { vitamin D }(<50)\end{array}$} & $\begin{array}{c}\text { With normal } \\
\text { vitamin D }(>50)\end{array}$ \\
\hline SSS & $16.74 \pm 8.08$ & $29.50 \pm 12.41$ & 0.002 \\
mRS & $4.89 \pm 0.31$ & $4.33 \pm 0.47$ & 0.03 \\
\hline
\end{tabular}

$p$-value was significant if $<0.05$.

SSS : Scandinavian Stroke Scale.

mRS: Modified Rankin Scale.

Table (6): Mean levels of bone minerals and parathormone hormone among survivors and deaths in our studied patients.

Patients with intracerebral hemorrhage $(\mathrm{No}=125)$

\begin{tabular}{llll} 
Parameters & $\begin{array}{c}\text { Survivors } \\
(\mathrm{n}=90,72 \%)\end{array}$ & $\begin{array}{c}\text { Dead } \\
(\mathrm{n}=35,28 \%)\end{array}$ & $\begin{array}{c}p- \\
\text { value* }\end{array}$ \\
\hline $\begin{array}{c}\text { Serum total Calcium } \\
(\mathrm{mg} / \mathrm{dl})(\text { Mean } \pm \mathrm{SD})\end{array}$ & $9.29 \pm 1.55$ & $9.21 \pm 1.43$ & 0.76 \\
$\begin{array}{c}\text { Serum Phosphorus } \\
(\mathrm{mg} / \mathrm{dl}) \text { (Mean } \pm \mathrm{SD})\end{array}$ & $4.53 \pm 0.83$ & $5.16 \pm 0.41$ & 0.001 \\
$\begin{array}{c}\text { Intact Parathormone } \\
\text { hormone (ng/ml) } \\
(\text { Mean } \pm \mathrm{SD})\end{array}$ & $69.09 \pm 15.67$ & $78.09 \pm 18.09$ & 0.46 \\
$\begin{array}{c}\text { Vitamin D (nmol/L) } \\
(\text { Mean } \pm \mathrm{SD})\end{array}$ & $38.93 \pm 8.93$ & $22.56 \pm 5.48$ & 0.001 \\
\hline
\end{tabular}

Data was expressed in form of mean \pm SD.

$p$-value was significant if $<0.05$.

*: Student $t$-test was used.

n: Number.

Table (7): Multivariate regression analysis for predictors of death in patients with cerebrovascular stroke.

\begin{tabular}{lccc}
\hline Variables & $\begin{array}{c}\text { Odd's } \\
\text { ratio }\end{array}$ & $\begin{array}{c}95 \% \text { confidence } \\
\text { interval }\end{array}$ & $\begin{array}{c}p \text { - } \\
\text { value }\end{array}$ \\
\hline Diabetes mellitus & 3.18 & $2.56-5.67$ & 0.02 \\
Hypertension & 1.45 & $1.90-4.65$ & 0.01 \\
Smoking & 0.56 & $0.9-1.4$ & 0.34 \\
Raised cholesterol & 1.9 & $1.22-3.89$ & 0.09 \\
Raised LDL & 1.6 & $0.99-3.2$ & 0.22 \\
decreased HDL & 1.76 & $1.34-3.46$ & 0.34 \\
Raised TGs & 1.11 & $1.98-3.22$ & 0.56 \\
Raised Phosphorous & 0.9 & $2.33-4.89$ & 0.98 \\
Decreased vit.D & 2.33 & $3.44-5.89$ & 0.03 \\
\hline
\end{tabular}

$p$-value was significant if $<0.05$.

LDL: Low density lipoprotein.

HDL: High density lipoprotein.

TGs : Triglycerides.

vit.D: VitaminD 


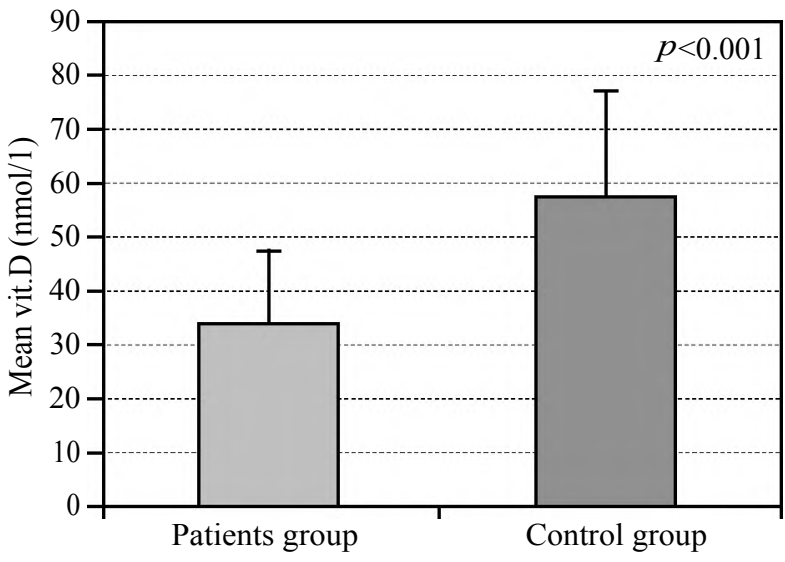

Fig. (1A): Level of vitamin D level in both studied groups.

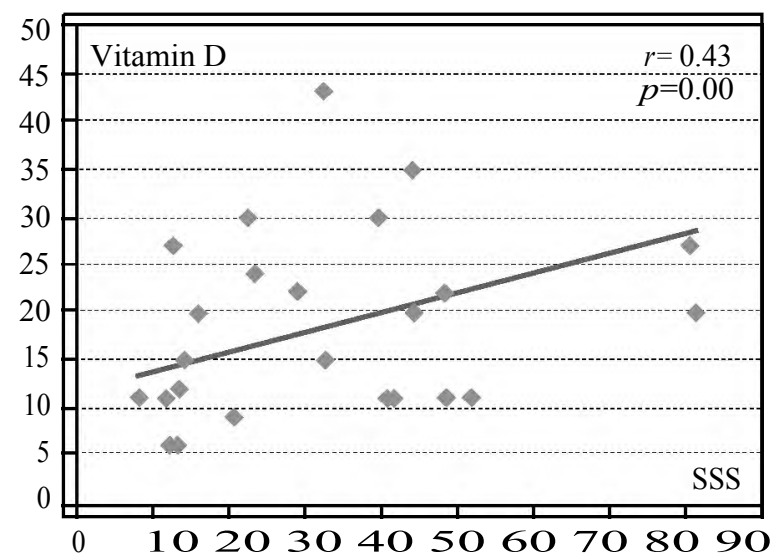

Fig. (2): Correlation between Vitamin D and Scandinavian Stroke Scale.

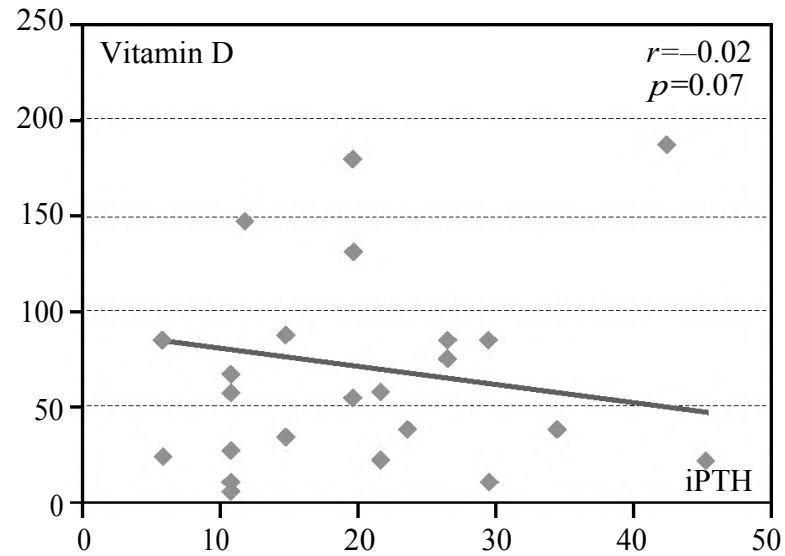

Fig. (4): Correlation between intact Parathormone Hormone and Vitamin D.

\section{Discussion}

Stroke is a standout amongst the most incapacitating neurological disorders and remains the second most general reason for death [1]. Patients with stroke have a few vascular risk factors which may incline to cardiovascular disease moreover.

Vitamin D insufficiency may be engaged in the advancement of many diseases, including hyper-

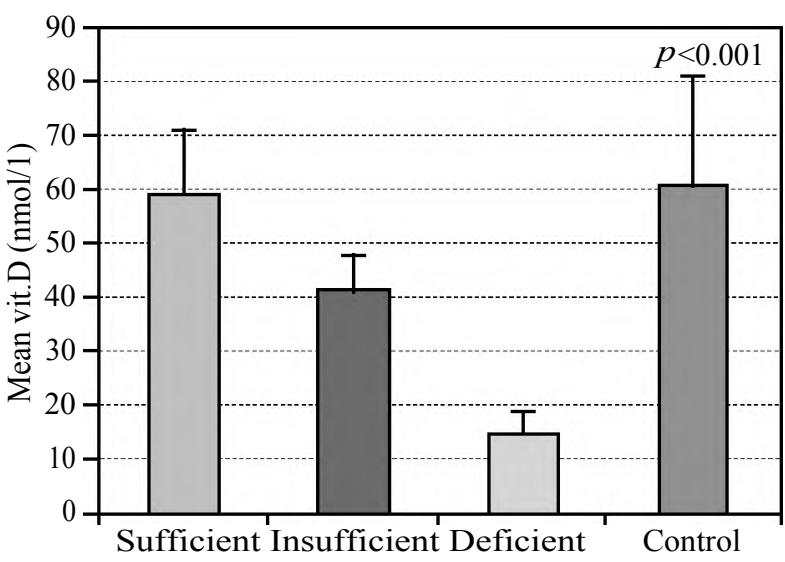

Fig. (1B): Level of vitamin D level in both studied groups.

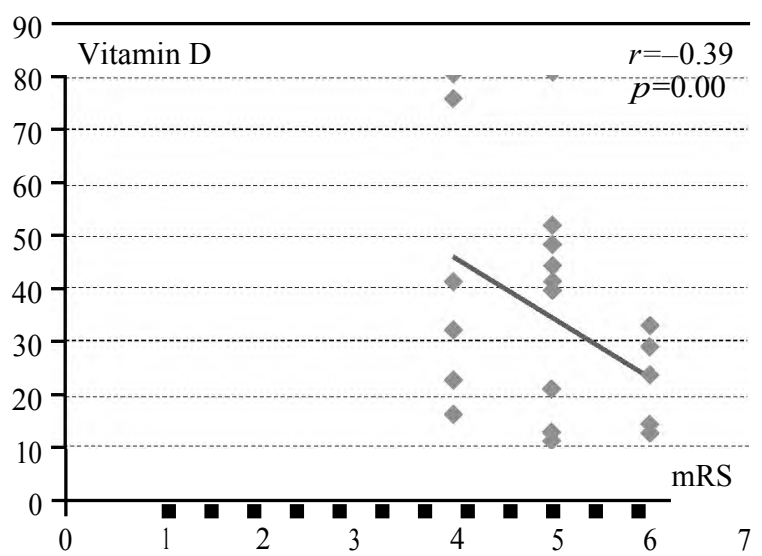

Fig. (3): Correlation between vitamin D and modified Rankin Scale.

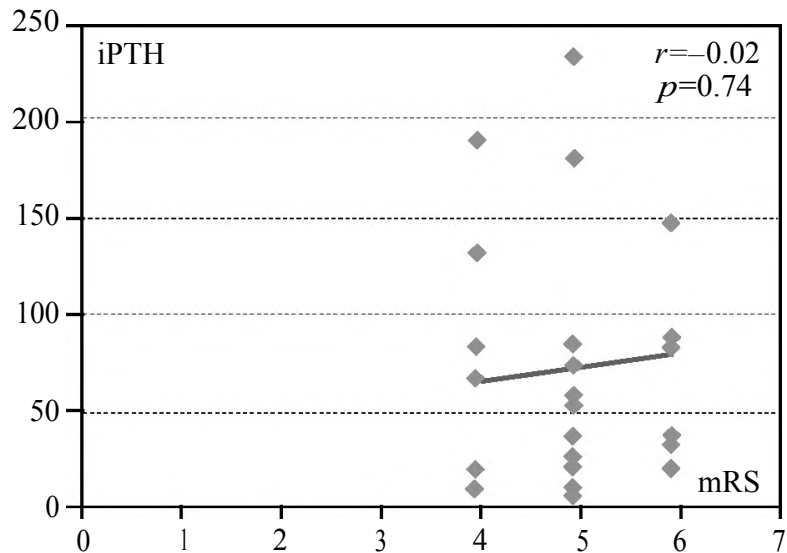

Fig. (5): Correlation between iPTH and modified Rankin Scale.

tension, diabetes mellitus, myocardial infarction and stroke. Lacking Vitamin D prompts to hyperparathyroidism, which may add to the instability of the atherosclerotic plaques. These vascular changes are finally to cause stroke [13]. A few investigations showing the status of vitamin $\mathrm{D}$ in connection with the danger of stroke morbidity or mortality have been inconsistent [5]. This study expected to evaluate the status of vitamin $\mathrm{D}$ in 
patients with intracerebral hemorrhage from Upper Egypt and to consider its relationship with stroke risk factors and its association with functional outcome.

In the present study, the larger part of our patients had low levels of vitamin D. This finding concurred with Thapa et al., [13] who expressed that there was a connection between the low circulating level of vitamin D and expanded danger of cerebrovascular disease recommending vitamin $\mathrm{D}$ supplementation as a hopeful methodology in the avoidance of strokes.

Be that as it may, Kikkinen et al., [6] found no relationship with occurrence hemorrhagic stroke. In addition, the vast majority of our patients with expanded risk factors for occurrence hemorrhagic stroke, for example, hypertension, diabetes mellitus, and dyslipidemia had altogether connected with the most minimal levels of vitamin $\mathrm{D}$, proposing part of vitamin $D$ in these risk factors prompting intracerebral hemorrhage.

These discoveries were as per Kikkinen et al., [6] and Anderson et al., [7] who expressed that hypertension, diabetes, and poor lipid profile were related to low serum vitamin D level. Burgaz et al., [14], Tamez and Thadhani [15] and Kunutsor et al., [16] announced that an opposite association between vitamin D levels and blood pressure and the predominance of arterial hypertension were found. Pokharel et al., [17] declared many mechanisms have been proposed the contribution of vitamin $\mathrm{D}$ in control of blood pressure and the pathophysiology of arterial hypertension, which is a noteworthy hazard factor for stroke.

Vitamin D insufficiency is related to increment in renin expression and angiotensin II creation, prompting to hypertension. Notably, Afzal et al., [18] and Song et al., [19] revealed that Low vitamin D levels have been observed to be related to type 2 diabetes and Pittas et al., [20] detailed a converse relationship between blood 25-hydroxyvitamin D (25OHD) concentration and occurrence of diabetes. Also, Zittermann et al., [21] declared that vitamin D insufficiency has been connected to dyslipidemia and Ponda et al., [22] showed that low vitamin D levels are related with higher triglycerides and total cholesterol yet low levels of HDL-cholesterol. Kazlauskaite et al., [23] acknowledged that vitamin $\mathrm{D}$ insufficiency is related with substantial highthickness lipoprotein particles; notwithstanding, Wang et al., [24] revealed no critical impact of vitamin D on total cholesterol, HDL cholesterol or triglycerides, however a possibly huge increment in LDL cholesterol. In any case, Skaaby et al., $[25,26]$ expressed that vitamin D status was not essentially connected with changes in absolute HDL and LDL cholesterol, with no relationship amongst it and hypertension. As opposed to our outcomes, Marcén et al., [27] and Kühn et al., [28] had announced no relationship between vitamin D and hazard factors for cardiovascular diseases.

In the current study, we found high iPTH levels in the patients. This finding was in agreement with van Ballegooijen et al., [29,30] and Pilz et al., [31] who stated that higher parathyroid hormone levels had been viewed as one of the critical hazard factors for cardiac and cerebrovascular diseases.

Moreover, we found a statistically significant inverse correlation between vitamin D levels and iPTH in our study. This result agreed with Pilz et al., [32] and Thapa et al., [13] who stated that the elevation in parathyroid hormone levels is viewed as a sign of vitamin D deficiency.

Chatterjee et al., [33] and Vaysman [34] stated that at the cellular level, the vitamin D presumably through VDR promotes cellular proliferation, differentiation, apoptosis, DNA repair and modulation of both cellular and innate immunity. It influences proliferation of vascular smooth muscles alongwith their migration and gene expression, elastogenesis and immunomodulation. All these are processes involved in the pathogenesis of atherosclerosis influencing various macrovascular disease processes as cardiovascular disease, peripheral vascular disease, and cerebro vascular accident. Notably, Dursun et al., [35] reported that Vitamin $\mathrm{D}$ can regulate neuronal differentiation and maturation by regulating the production of neurotrophic factors including nerve growth factor and glial cell line derived neurotrophic factor and serves as a neuroprotective agent. Vitamin D is a potent antioxidant through inhibition of free radical generation by nitric oxide synthase and gamma-glutamyl transpeptidase. Thus, vitamin D appears to a play an important role in vascular health of the brain.

Interestingly, we found statistically significant more deficient levels of vitamin $\mathrm{D}$ in our deaths among our study. This finding was inconsistent with Pilz et al., [32] and Zittermann et al., [36] who stated that low vitamin D levels were an independent risk factor for death. Semba et al., [37], Virtanen et al., [38] and Tu et al., [39] showed an association between low serum vitamin $\mathrm{D}$ and high rate of mortality. Therefore, According to these results, we could conclude that vitamin D is a marker for prognosis, functional outcome, and death in patients with acute ischemic and hemorrhagic stroke. 
However, Cawthon et al, [40] and Hutchinson et al., [41] found no correlation. Holick [42] had also demonstrated that vitamin D deficiency is a not documented independent risk factor for cardiovascular diseases (CVD) and death.

The possible pathophysiological mechanisms underlying an association of vitamin D with total mortality are not completely stated. The association of the lowest levels of vitamin $\mathrm{D}$ with diabetes mellitus, hypertension and high lipid profile as risk factors for atherosclerosis and cardiovascular diseases, in addition to hyperparathyroidism in our deaths, could explain their key causative roles suggesting the protective vitamin D effects against those conditions.

In the current study, we found statistically significant higher iPTH levels among deaths. This could be explained by that higher serum iPTH levels have been associated with subclinical vascular disease, impaired endothelial function, and increased aortic pulse pressure. Our results were in concordance with Korada et al., [43] who stated that elevated PTH levels have also been associated with increased risk of occurrence of hypertension, cardiovascular mortality, sudden cardiac death, heart failure and all-cause mortality.

Moreover, Hagström et al., [44] reported that mild elevations of PTH could be associated with an amplified risk of cardiovascular morbidity and death. Interestingly, we found statistically significant high serum levels of phosphorous in spite of normal serum levels of $\mathrm{Ca}$ among our deaths. These findings were in concordance with Paratibha et al., [45] who stated that patients with higher serum phosphate had a significantly higher incidence of deaths or recurrent vascular events. Yamada et al., [46]found that higher serum phosphate levels were significantly associated with an increased risk of brain hemorrhage, even after adjusting for potential confounding factors.

Our finding could be explained by that Phosphate loading directly induced inflammation in vascular smooth muscle cells and increased the expression of matrix metalloproteinases II and IX which degrade extracellular matrix and disrupt the integrity of vascular layers. Moreover, high Phosphate loading induced an apoptosis for vascular smooth muscle cells and endothelial cells through oxidative stress and inflammation [47].

These results were in agreement with Bihl et al., [48] who affirmed that vascular inflammation is one possible clarification for the association between hyperphosphatemia and brain hemorrhage. Furthermore, Paloian et al., [49], Wang et al., [50] and Legati et al., [51] who stated that phosphate overload may induce calcification for vascular cells via changes of vascular smooth muscle cells into bone forming cells, apoptosis of vascular smooth muscle cells, and degradation of extracellular matrix in the arterial wall may also play a role in the association between serum phosphate levels and brain hemorrhage.

In contrast to our finding related to the normal serum level of calcium among deaths, You et al., [52] reported that elevated calcium level during admission is associated with outstanding outcomes at hospital discharge and after three months among acute intracerebral hemorrhage patients. Conversely, elevated phosphate was not associated with either outcome. Additionally, Inoue et al., [53] found that low serum calcium levels during admission were associated with larger hematoma volume and higher NIHSS score, but there was no significant association with 30-day outcome. Chatterjee et al., [33] stated that most of the acute stroke patients whatever its types had low serum calcium levels.

Our study demonstrated a statistically significant positive correlation between low vitamin $\mathrm{D}$ levels and severity of stroke in our patients with a statistically significant inverse correlation for functional outcome. These results were in agreement with Bakradze et al., [54] who found that intracerebral hemorrhage patients with severe vitamin D deficiency had significantly poorer stroke severity, where NIHSS on admission was higher in those patients with severe vitamin D deficiency, in spite, there was no statistical significance between vitamin D level and discharge $\mathrm{mRS}$ score.

A limitation of this study was our unique population consisting of Egyptian people living in Upper Egypt which may limit generalization to other areas of Egypt; therefore, further researches are needed. Notably, it was performed at a single center, and the sample size was small with no seasonal adjustment for vitamin D levels or assessing its causality to determine the association between vitamin-D level and stroke. Another limitation was the lack of information on sunlight exposure and vitamin D supplement use, all of which may have a significant impact on vitamin D status. So, it is recommended to perform multicenter researches involving a large number of population. Also, vitamin D therapy for all patients with cerebrovascular stroke is recommended from 
the onset of insult. We concluded that low levels of vitamin D are independently predictor for unfavorable outcome in acute intracerebral hemorrhagic stroke and it is a marker of mortality suggesting that vitamin D medications is a hopeful approach in the avoidance of stroke.

Disclosures: None.

\section{References}

1- MUKHERJEE D. and PATIL C.G.: Epidemiology and the global burden of stroke.World Neurosurg. Dec., 76 (6 Suppl): S85-90, 2011.

2- QURESHI A.I., MOHAMMED Y.M., et al.: A prospective multi-center study to evaluate the feasibility and safety of the aggressive antihypertensive treatment in patients with acute intracerebral hemorrhage. J. Intensive Care. Med., 20: 34-42, 2005.

3- KREMER P.H.C., JOLINK W.M.T., KAPPELLE L.J., ALGRA A., KLIJN C.J.M., SMART and ESPRIT Study Groups: Risk Factors for Lobar and Non-Lobar Intracerebral Hemorrhage in Patients with Vascular Disease. PLoS One, 10 (11): e0142338, 2015.

4- TAN L.M., WANG L.U., CHEN J.J., LI H. and LUO W.B.: Diagnostic performance of bone metabolic indexes for the detection of stroke. Saudi Med. J. Jan., 38 (1): 30 35, 2017.

5- SUN Q., PAN A., HU F.B., MANSON J.E. and REXRODE K.M.: 25-hydroxyvitamin D levels and risk of stroke: A prospective study and meta-analysis. Stroke, 43: 14707, 2012.

6- KIKKINEN A., KNERT P., ARO A., RISSANEN H., MARNIEMI J., HELIÖVAARA M., IMPIVAARA O. and REUNANEN A.: Vitamin D status and the risk of cardiovascular disease death. Am. J. Epidemiol., 170: 1032-1039, 2009.

7- ANDERSON J.L., MAY H.T., HORNE B.D., BAIR T.L., HALL N.L., CARLQUIST J.F., LAPPÉ D.L. and MUHLESTEIN J.B.: Intermountain Heart Collaborative (IHC) Study Group. Relation of vitamin D deficiency to cardiovascular risk factors, disease status, and incident events in a general healthcare population. Am. J. Cardiol., 106: 963-968, 2010.

8- WANG Y., JI H., TONG Y., et al.: Prognostic value of serum 25-hydroxyvitamin D in patients with stroke. Neurochem. Res., 39: 1332-1337, 2014.

9- GUPTA A., PRABHAKAR S., MODI M., BHADADA S.K., LAL V. and KHURANA D.: Vitamin D status and risk of ischemic stroke in North Indian patients. Indian Journal of Endocrinology and Metabolism. Sep-Oct., Vol., 18, Iss. 5: 721-5, 2014.

10- MICHOS E.D., and GOTTESMAN R.F.: Vitamin D for the prevention of stroke incidence and disability: Promising but too early for prime-time. Eur. J. Neurol. January, 20 (1): 3-4, 2013.

11- DAUBAIL B., JACQUIN A., GUILAND J.C., KHOURY C., ABOA-EBOULÉ C., GIROUD M. and BÉJOT Y.: Association between serum concentration of vitamin $\mathrm{D}$ and 1-year mortality in stroke patients. Cerebrovasc Dis., 37: 364-367, Diabetes Care, 36: 1422-1428, 2014.
12- TU W.J., DONG X., ZHAO S.J., et al.: Prognostic value of plasma neuroendocrine biomarkers in patients with acute ischemic stroke. J. Neuroendocrinol., 25: 771-778, 2013.

13-THAPA L., SHRESTHA A., PRADHAN M., BHANDARI T.R., SHRESTHA S., POUDEL R.S., POKHREL B. and POUDEL R.: Status of vitamin D and its association with stroke risk factors in patients with acute ischemic stroke in a tertiary care hospital. J. Nepal. Med. Assoc., 52 (195): 935-39, 2014

14- BURGAZ A., ORSINI N., LARSON S.C. and WOLK A.: Blood 25-hydroxyvitamin D concentration and hypertension: A meta-analysis. J. Hypertens, 29: 636-645, 2011.

15- TAMEZ H. and THADHANI R.I.: Vitamin D and hypertension: An update and review. Curr. Opin. Nephrol. Hypertens, 21: 492-9, 2012.

16- KUNUTSOR S.K., APEKEY T.A. and STEUR M.: Vitamin D and risk of future hypertension: A meta-analysis of 283,537 participants. Eur. J. Epidemiol. Mar., 28 (3): 205-21, 2013

17- POKHAREL B.R., KHAREL G., THAPA L.J. and RANA P.V.S.: Vitamin D and other risk factors among stroke patients. Kathmandu Univ. Med. J., 49 (1): 71-3, 2015.

18-AFZAL S., BOJESEN S.E. and NORDESTGAARD B.G. Low 25-hydroxyvitamin D and risk of type 2 diabetes: A prospective cohort study and meta-analysis. Clin. Chem., 59: 381-391, 2013.

19- SONG Y., WANG L., PITTAS A.G., DEL GOBBO L.C., ZHANG C., MANSON J.E. and HU F.B.: Blood 25hydroxyvitamin D levels and incident type 2 diabetes: A meta-analysis of prospective studies, 2013.

20- PITTAS A.G.1, DAWSON-HUGHES B.2, SHEEHAN P.R.3, ROSEN C.J.4, WARE J.H.5, KNOWLER W.C.6 and STATEN M.A.7: Rationale and design of the Vitamin D and Type 2 Diabetes (D2d) study: A diabetes prevention trial. D2d Research Group. Diabetes Care. Dec., 37 (12): 3227-34, 2014.

21- ZITTERMANN A., GUMMERT J.F. and BÖRGERMANN J.: The role of vitamin $D$ in dyslipidemia and cardiovascular disease. Curr. Pharm. Des., 17: 933-42, 2011.

22- PONDA M.P., DOWD K., FINKELSTEIN D., HOLT P.R. and BRESLOW J.L.: The Short-Term Effects of Vitamin D Repletion on Cholesterol: A Randomized PlaceboControlled Trial. Arterioscler Thromb. Vasc. Biol. October, 32 (10): 2510-2515, 2012.

23- KAZLAUSKAITE R., POWELL L.H., MANDAPAKAL C., CURSIO J.F., AVERY E.F. and CALVIN J.: Vitamin $\mathrm{D}$ is associated with atheroprotective high-density lipoprotein profile in postmenopausal women. J. Clin. Lipidol., 4: 113-119, 2010

24- WANG L., SONG Y., MANSON J.E., et al.: Circulating 25-hydroxyvitamin D and risk of cardiovascular disease: A meta-analysis of prospective studies. Circ. Cardiovasc. Qual. Outcomes, 5: 819-829, 2012a.

25- SKAABY T., HUSEMOEN L.L., PISINGER C., JORGENSEN T., THUESEN B.H., FENGER M. and LINNEBERG A.: Vitamin D status and changes in cardiovascular risk factors: A prospective study of a general population. Cardiology, 123 (1): 62-70, 2012 
26- SKAABY T. , HUSEMOEN L.L., PISINGER C., JORGENSEN T., THUESEN B.H., FENGER M. and LINNEBERG A.: Vitamin D status and cause-specific mortality: A general population study. PLoS One, 7 (12): $\mathrm{e} 52423,2012 \mathrm{~b}$

27- MARCÉN R., JIMENEZ S., FERNÁNDEZ-RODRIGUEZ A., GALEANO C., VILLAFRUELA J.J., GOMIS A., et al.: Are low levels of 25-hydroxyvitamin D a risk factor for cardiovascular disease or malignancies in renal transplantation. Nephrol. Dial Transplant, 27 (Suppl 4): iv47$52,2012$.

28- KÜHN T., KAAKS R., TEUCHER B., HIRCHE F., DIERKES J., WEIKERT C., KATZKE V., BOEING H., STANGL G.I. and BUIJSSE B.: Plasma 25-hydroxy vitamin D and its genetic determinants in relation to incident myocardial infarction and stroke in the European prospective investigation into cancer and nutrition (EPIC), Germany study. PloS One, 8: e69080, 2013.

29- VAN BALLEGOOIJEN A.J., REINDERS I., VISSER M., DEKKER J.M., NIJPELS G., STEHOUWER C.D. and PILZ S., BROUWER I.A.: Serum parathyroid hormone in relation to all-cause and cardiovascular mortality: The Hoorn study. J. Clin. Endocrinol. Metab., 98: E638-E645, 2013a.

30- VAN BALLEGOOIJEN A.J., REINDERS I., VISSER M. and BROUWER I.A. 2013b: Parathyroid hormone and cardiovascular disease events: A systematic review and meta-analysis of prospective studies. Am. Heart. J., 165: 655-664, 2013a.

31- PILZ S., TOMASCHITZ A., DRECHSLER C., DEKKER J.M. and MÄRZ W.: Vitamin D deficiency and myocardial diseases. Mol. Nutr. Food Res., 54: 1103-13, 2010.

32- PILZ S., GAKSCH M., O' HARTAIGH B., TOMASCHITZ A. and MÄRZ W.: The role of vitamin D deficiency in cardiovascular disease: Where do we stand in 2013? Arch. Toxicol., 87: 2083-2103, 2013.

33- CHATTERJEE K., MANDAL S.K., CHATTERJEE S., SARKAR P., MONDAL S.S., GANGULY J., SARDAR D., MANI S. and DAS B.: Assesment of vitamin D in cerebrovascular accident patients in Eastern India. National Journal of Medical Research, Vol. 4. 4, Oct-Dec., 264269.

34- VAYSMAN A.M.: Protective role of vitamin D on the cardiovascular system. US. Pharm., 35 (2): HS28-HS32, 2010.

35- DURSUN E., GEZEN-AK D. and YILMAZER S.: A new mechanism for amyloid-B induction of iNOS: Vitamin D -VDR pathway disruption. J. Alzheimers Dis., 36: 45974, 2013.

36- ZITTERMANN A., IODICE S., PILZ S., GRANT W.B., BAGNARDI V. and GANDINI S.: Vitamin D deficiency and mortality risk in the general population: A metaanalysis of prospective cohort studies. Am. J. Clin. Nutr., 95: 91-100, 2012

37- SEMBA R.D., HOUSTON D.K., BANDINELLI S., SUN K., CHERUBINI A., CAPPOLA A.R. and GURALNIK J.M. and FERRUCCI L.: Relationship of 25 - hydroxyvitamin D with all-cause and cardiovascular disease mortality in older community-dwelling adults. Eur. J. Clin. Nutr., 64: 203-209, 2010.
38- VIRTANEN J.K., NURMI T., VOUTILAINEN S., MURSU J. and TUOMAINEN T.P.: Association of serum 25hydroxyvitamin $\mathrm{D}$ with the risk of death in a general older population in Finland. Eur. J. Nutr., 50: 305-3 12, 2011.

39- TU W.J., ZHAO S.J., XU D.J., et al.: Serum 25hydroxyvitamin D predicts the short-term outcomes of Chinese patients with acute ischemic stroke. Clin. Sci., 126 (5): 339-346, 2014.

40- CAWTHON P.M., PARIMI N., BARRETT-CONNOR E., LAUGHLIN G.A., ENSRUD K.E., HOFFMAN A.R., SHIKANY J.M. , CAULEY J.A., LANE N.E., BAUER D.C., ORWOLL E.S. and CUMMINGS S.R. : Serum 25hydroxyvitamin $\mathrm{D}$, parathyroid hormone, and mortality in older men. J. Clin. Endocrinol. Metab., 95: 4625-4634, 2010 .

41- HUTCHINSON M.S., GRIMNES G., JOAKIMSEN R.M., FIGENSCHAU Y. and JORDE R.: Low serum 25hydroxyvitamin D levels are associated with increased allcause mortality risk in a general population: The Tromso study. Eur. J. Endocrinol., 162: 935-942, 2010.

42- HOLICK M.F.: Vitamin D deficiency. N. Engl. J. Med., 357: 266-281, 2007.

43- KORADA S.K., ZHAO D.I., GOTTESMAN R.F., GUALLAR E., LUTSEY P.L., ALONSO A., SHARRETT A.R., POST W.S., REIS J.P., MOSLEY T.H. and MICHOS E.D.: Parathyroid Hormone and Subclinical Cerebrovascular Disease: The Atherosclerosis Risk in Communities (ARIC) Brain MRI Study J. Stroke Cerebrovasc Dis., April., 25 (4): 883-893.

44- HAGSTRÖM E.L., RUTA K., ELNA-MARIE N., KARL L., HÅKAN M., HÅKAN M., LARS A., LARS J. and ÄRNLÖV LJ.: Plasma Parathyroid Hormone Is Associated with Vascular Dementia and Cerebral Hyperintensities in Two Community-Based Cohorts. Journal of Clinical Endocrinology \& Metabolism, Volume 99, Issue 11, 1 November, Pages, 4181-4189, 2014.

45- PRATIBHA S., PRAVEEN-KUMAR S. and AGADI J.B.: Increased Serum Alkaline Phosphatase and Serum Phosphate as Predictors of Mortality after Stroke. J. Clin. Diagn. Res. Aug., 8 (8): CC01-CC03, 2014.

46- YAMADA S., TSURUYA K., TANIGUCHI M., TOKUMOTO M., FUJISAKI K., HIRAKATA H., FUJIMI S. and KITAZONO T.: Association Between Serum Phosphate Levels and Stroke Risk in Patients Undergoing Hemodialysis The Q-Cohort Study. Stroke, 47: 21892196, 2016.

47- YAMADA S., TOKUMOTO M., MATSUMOTO N., TANIGUCHI M., NOGUCHI H. and NAKANO T., et al.: Phosphate overload directly induces systemic inflammation and malnutrition as well as vascular calcification in uremia. Am. J. Physiol. Renal. Physiol., 306: F1418F1428, 2014.

48- BIHL J.C., ZHANG C., ZHAO Y., XIAO X., MA X. CHEN Y., et al.: Angiotensin- (1-7) counteracts the effects of Ang II on vascular smooth muscle cells, vascular remodeling and hemorrhagic stroke: The role of the NF $\mathrm{\kappa B}$ inflammatory pathway. Vascul. Pharmacol., 73: 115-123, 2015.

49- PALOIAN N.J. and GIACHELLI C.M.: A current understanding of vascular calcification in CKD. Am. J. Physiol. 
Renal. Physiol., 307: F891-F900. doi:10.1152/ajprenal. 00163. 32, 2014.

50- WANG C., LI Y., SHI L., REN J., PATTI M., WANG T., et al.: Mutations in SLC20A2 link familial idiopathic basal ganglia calcification with phosphate homeostasis. Nat. Genet., 44: 254-256, 2012.

51- LEGATI A., GIOVANNINI D., NICOLAS G., LÓPEZSÁNCHEZ U., QUINTÁNS B., OLIVEIRA J.R., et al.: Mutations in XPR 1 cause primary familial brain calcification associated with altered phosphate export. Nat. Genet., 47: 579-581, 2015.

52- YOU S., HAN Q., XU J., ZHONG C., ZHANG Y., LIU
H., ZHANG Y., XU X., LIU C. and CAO Y.: Serum Calcium and Phosphate Levels and Short- and Long-Term Outcomes in Acute Intracerebral Hemorrhage Patients. Journal of Stroke and Cerebrovascular Diseases, Vol. 25, No. 4 (April), pp 914-920, 2016.

53-INOUE Y., MIYASHITA F., TOYODA K., et al.: Low serum calcium levels contribute to larger hematoma volume in acute intracerebral hemorrhage. Stroke, 44: 2004-2006, 2013.

54- BAKRADZE E., MCCULLOUGH L., STAFF I. and NOAH A.: Vitamin D deficiency correlates with stroke severity on presentation in intracerebral hemorrhage. Stroke. Feb., Vol., 47, Iss. Supp., 1, 2016.

\section{فيتامين (د ) ونزف المخ الذاتى: \\ هل سيكون عونائ (دنز الهن}

خلفية البحث والغرض من البحث: يعد أزدياد النقص فى فيتا مين (د) عاملاً خطراً للسكتة الدماغية. وقد يساعد تحديد فيتامين

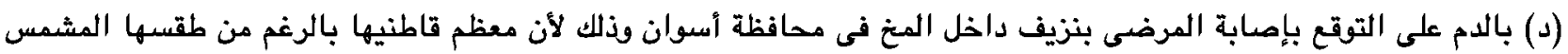

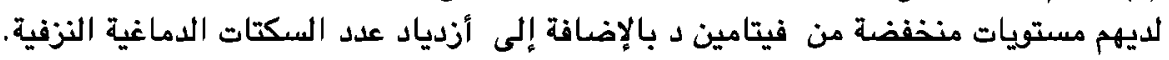

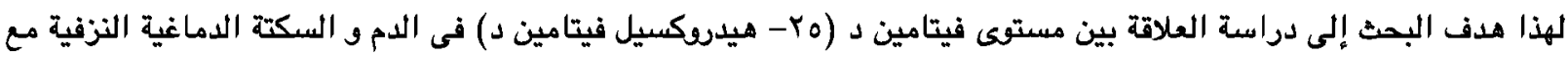

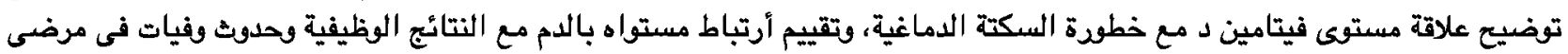
النزيف داخل المخغ. تصنيع.

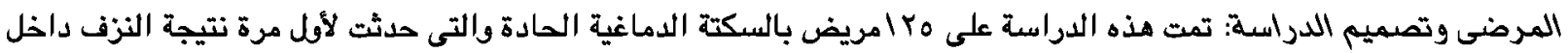

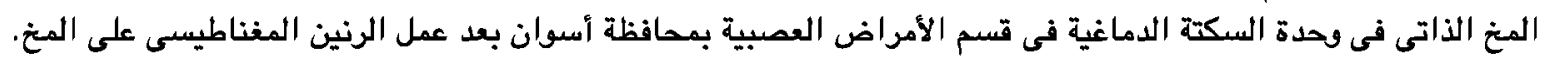

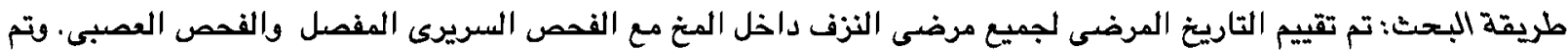

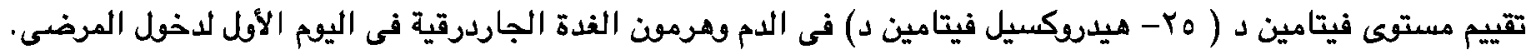

نتائج البحث: لقد أثبتت الدراسة أن ع \& من المرضى بالنزيف داخل المخ لديهم نقص ذو دلالة إحصائية قيمة بمستويات فيتامين

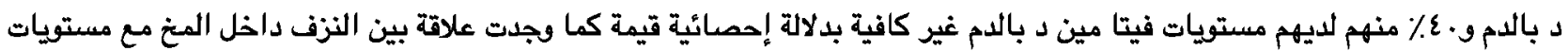

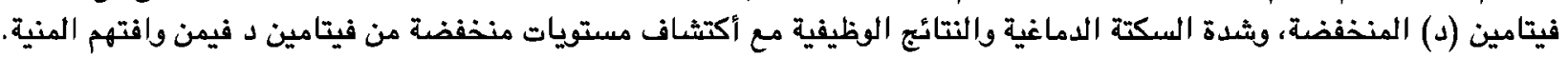

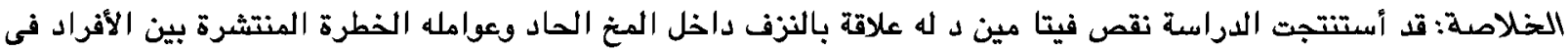

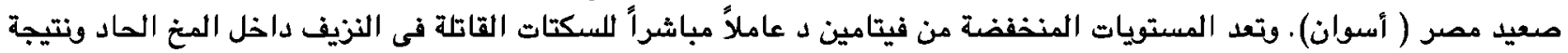

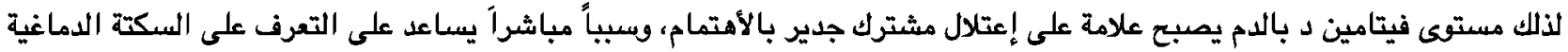

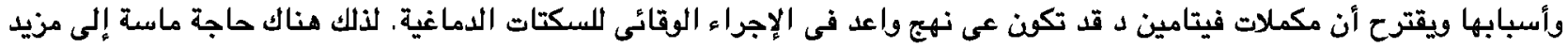

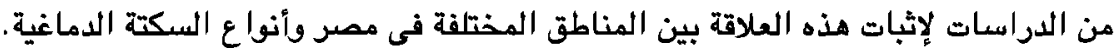

